\title{
Settlement and recruitment of the sea urchin Paracentrotus lividus in two contrasting habitats in the Mediterranean
}

\author{
F. Tomas ${ }^{1, *}$, J. Romero' ${ }^{1}$, X. Turon ${ }^{2}$ \\ ${ }^{1}$ Departament d'Ecologia, Universitat de Barcelona, and ${ }^{2}$ Departament de Biologia Animal, Invertebrats, \\ Universitat de Barcelona, Av. Diagonal 645, 08028 Barcelona, Spain
}

\begin{abstract}
We measured settlement and recruitment of one of the main invertebrate herbivores in the Mediterranean, the sea urchin Paracentrotus lividus, in 2 neighbouring and contrasting habitats: a seagrass meadow and a vertical rock wall. We quantified and compared temporal and bathymetrical variability in settlement and compared settlement with recruitment over a 4 yr period. Two settlement peaks were observed each year, a main peak in spring-early summer and a second peak in autumn-early winter. Interannual variability in settlement was very high (ca. 1 order of magnitude). Settlement was generally higher on the rock wall than in the seagrass meadow. No appreciable successful recruitment was observed in the meadow during the 4 yr studied despite the arrival of settlers. The few juvenile urchins found in the meadow were encountered at the shallow part and were completely hidden between the rhizomes. However, no differential settlement on the rhizome stratum was observed. In contrast to the seagrass meadow, recruitment occurred every year on the rock wall. Despite the arrival of settlers in both habitats, the population in the seagrass meadow appears to be recruitment-limited and probably mainly sustained by immigration, while settlement and recruitment appear to determine, to a certain extent, adult population structure and dynamics on the rock wall.
\end{abstract}

KEY WORDS: Population dynamics $\cdot$ Echinoid $\cdot$ Algal assemblage $\cdot$ Seagrass $\cdot$ Paracentrotus lividus Posidonia oceanica

Resale or republication not permitted without written consent of the publisher

\section{INTRODUCTION}

Sea urchins are among the invertebrates that play a major role in structuring and controlling benthic macrophyte communities. They are often considered strong interactors as changes in their relative abundance can dramatically change community composition and structure (Paine 1992, Sala \& Graham 2002), sometimes causing severe overgrazing events with complete denudation of algal or seagrass communities (see reviews by Lawrence \& Sammarco 1982 or Valentine \& Heck 1999). Their key role in benthic communities explains the interest of marine ecologists in different aspects of their biology and ecology, and the extensive literature devoted to these issues (e.g. Lawrence \& Sammarco 1982, Jangoux \& Lawrence 1983, Lawrence 2001).

Several processes (e.g. predation, recruitment, migration, disease) exert a crucial role in sea urchin population dynamics and therefore influence their structure (e.g. Watanabe \& Harrold 1991, Hagen 1995, McClanahan 1998, Scheibling et al. 1999). Among these, settlement and recruitment are probably of major relevance, as is known for marine invertebrates with planktonic larvae (Gaines \& Roughgarden 1985, Underwood \& Fairweather 1989, Minchinton \& Scheibling 1991). In fact, early benthic stages are major bottlenecks in many invertebrate life histories (Gosselin \& Qian 1997, Hunt \& Scheibling 1997).

Echinoids undergo conspicuous interannual variations in recruitment, whereby successful years are interspersed with years of poor recruitment (Ebert 1983, Sala et al. 1998, Balch \& Scheibling 2000). The conspicuous variability in recruitment can easily mask any evidence of other underlying processes regulating population dynamics (Fogarty et al. 1991). Thus, more research is needed to achieve a full understanding of the importance of the early stages of the life history 
in regulating sea urchin abundance and population structure. To contribute to this end, we evaluate the variability in settlement and recruitment and their relative importance in determining the population structure and dynamics of the sea urchin Paracentrotus lividus in 2 representative, as well as contrasting, habitats in the Mediterranean.

Paracentrotus lividus (Lamarck) is one of the most important invertebrate herbivores in Mediterranean waters (Boudouresque \& Verlaque 2001), exerting a significant effect on algae, even at low densities (Palacín et al. 1998a), and in seagrass communities (Alcoverro et al. 1997). Whereas P. lividus is generally found at low densities in Posidonia oceanica (L.) Delile meadows (0 to 6 individuals (ind.) $\mathrm{m}^{-2}$, e.g. Verlaque \& Nédelec 1983, Palacín et al. 1998b), densities of 10 to 30 ind. $\mathrm{m}^{-2}$ are often encountered in shallow, hard substrate algal assemblages (e.g. Fenaux et al. 1987, Benedetti-Cecchi \& Cinelli 1995, Sala et al. 1998). P. lividus recruits are typically found in dense algal assemblages, rocky crevices and under boulders (e.g. Kempf 1962, Verlaque 1984, Sala \& Zabala 1996). In contrast, $P$. lividus juveniles are generally absent or at very low densities in $P$. oceanica meadows (Azzolina 1988, San Martin 1995, but see Azzolina \& Willsie 1987).

The apparently contrasting juvenile and adult population structures of Paracentrotus lividus generally observed in these 2 habitats could be the result of different settlement and recruitment patterns. We therefore evaluated settlement and recruitment of this species in both habitats to investigate the extent to which these processes can explain the differences in adult populations often encountered.

In the present study, we quantify settlement on artificial collectors in a variety of ecological conditions and measure recruitment from the abundance of juvenile sea urchins. Our specific goals were (1) to quantify and compare temporal (intra- and inter-annual) and bathymetrical variability of Paracentrotus lividus settlement between a Posidonia oceanica meadow and an algal assemblage on a vertical rock wall and (2) to compare settlement with recruitment and adult population structure over a 4 yr period.

\section{MATERIALS AND METHODS}

Study site. The study was carried out in the Medes Islands Marine Reserve (NE coast of Spain, northwestern Mediterranean Sea, $42^{\circ} 2^{\prime} \mathrm{N}, \quad 3^{\circ} 13^{\prime} \mathrm{E}$ ) between 2.5 and $10 \mathrm{~m}$ depth, where surface water temperature ranges between approximately $12^{\circ} \mathrm{C}$ in winter and $24^{\circ} \mathrm{C}$ in summer. This area contains a south-facing, vertical rock wall reaching from the sur- face to $6 \mathrm{~m}$ depth, where the slope becomes subhorizontal and the seagrass Posidonia oceanica meadow begins on sedimentary substratum, extending to more than $15 \mathrm{~m}$ depth. Sampling took place in these 2 contrasting habitats, which have the same degree of exposure to waves and currents. The sampling site at the rock wall was ca. $300 \mathrm{~m}$ away from that in the seagrass meadow. More details about this area can be found in Alcoverro et al. (1997) and Sala et al. (1998). At each habitat, samplings were undertaken within approximately $60 \mathrm{~m}$ of the coastline. The algal assemblage on the vertical rock wall was mainly composed of an erect stratum containing the Dictyotaceae Dictyota dichotoma, D. fasciola, Taonia atomaria and Padina pavonica, Halopteris spp. and Corallina elongata, and an understorey stratum of crustose calcareous algae Mesophyllum alternans and Litophyllum incrustans.

Settlement measurements. Settlement of Paracentrotus lividus was measured with artificial collectors (Ebert et al. 1994, Balch et al. 1998). Scrub brushes with vegetal bristles were used as they are easily treatable and effective for $P$. lividus (Hereu et al. 2004). Brushes had an $18 \times 6 \mathrm{~cm}$ wooden base with $2.5 \mathrm{~cm}$ long vegetal bristles. Individual brushes were attached to rope lines, suspended in the water column with a small subsurface float and anchored to the bottom. Brushes were collected in situ by SCUBA divers, carefully detached from the anchor and buoy, sealed underwater in individual plastic bags, kept in an ice chest and transported to the laboratory for further sorting. On the same sampling event, collected brushes were replaced by new ones. There were at least 3 brushes per experimental condition. Settlers were removed by rinsing the brushes with a highpressure freshwater shower while rubbing bristles by hand (Hereu et al. 2004). The water was then subsequently filtered through a $250 \mu \mathrm{m}$ sieve and the material collected from the filter was preserved in $70 \%$ ethanol in glass vials. Samples were sorted under a stereomicroscope, settled urchins were identified and test diameter (TD) was measured using a calibrated ocular micrometer. Both newly settled $P$. lividus and another echinoid species, Arbacia lixula, were found on collectors. We define settlers as newly arrived individuals on artificial samplers (i.e. postlarvae and early juveniles; Gosselin \& Jangoux 1998). The following aspects of settlement variability were explored.

Temporal and depth variability in settlement. Seasonal variability of settlement was monitored weekly or bi-weekly from April 2000 to July 2001. To assess interannual variability, additional samplings were performed in autumn-winter 2002 and early summer 2003. To assess depth variability, the seasonal monitor- 
ing was performed at 3 and $5 \mathrm{~m}$ depth on the rock wall and at 3,5 and $10 \mathrm{~m}$ in the seagrass meadow (from April 2000 until July 2001; after this time settlement was measured at $5 \mathrm{~m}$ depth at both habitats). Brushes generally remained underwater for 1 or $2 \mathrm{wk}$, depending on the sampling period. To make data comparable, arrival of settlers was expressed as the number of settlers per collector and per week.

Stratum variation in settlement. As juvenile and adults of Paracentrotus lividus are generally found between the rhizomes of Posidonia oceanica when inhabiting seagrass meadows (Kempf 1962, Azzolina 1988, F. Tomas pers. obs.), we wanted to determine whether there was a difference between settlement on the rhizomes and on the leaves. During the spring peak of 2000 (May to June, $\mathrm{n}=6$ sampling events), collectors were deployed at 2 different heights within the leaf canopy in the seagrass meadow: at the top of the leaf canopy and near the rhizomes (without touching the seafloor).

Measurement of recruits and adult populations. Measurements of juvenile and adult sea urchin abundance were undertaken monthly from May 2000 to September 2001 and once a year thereafter until 2003 (i.e. September 2002 and 2003). Similarly, population size structure was assessed during the same time period, but measurements were carried out every 2 mo from May 2000 to September 2001 and also in September 2002 and 2003. Due to physical differences in the 2 habitats and differences in the distribution of Paracentrotus lividus between them, variations in the method of sampling were required, as detailed below.

For the seagrass meadow, 40 randomly placed $0.25 \mathrm{~m}^{2}$ quadrats were sampled on transects positioned at 3 depth ranges (i.e. 40 quadrats at each depth range; approximately $2.5-4.0,5.0-6.0$ and $9.5-10.5 \mathrm{~m}$ ); each transect was no more than $50 \mathrm{~m}$ away from the others. For the rock wall, 20 quadrats were randomly sampled between approximately 2.5 and $3.6 \mathrm{~m}$ depth and 20 more between 3.7 and $5.6 \mathrm{~m}$ depth. Since the rock wall ended at $6 \mathrm{~m}$, no sampling at $10 \mathrm{~m}$ was possible there. The number of replicates were decided according to previous work (Turon et al. 1995, Sala et al. 1998, F. Tomas unpubl. data). All Paracentrotus lividus found in the quadrats were counted.

Measurements of population size structure were carried out by measuring the first 100 to 200 individuals found along randomly located transects (by surveying a band $1 \mathrm{~m}$ wide along the transect), encompassing an area of approximately 15 to $20 \mathrm{~m}^{2}$ (Sala et al. 1998). The individuals were measured (TD without spines) to the nearest mm using callipers.

We define recruitment as the appearance of small individuals $\geq 5 \mathrm{~mm}$ TD (below this size we could not reliably discern them underwater in the transects) and less than $16 \mathrm{~mm}$ TD (<1 yr age; Azzolina \& Willsie 1987, Fenaux et al. 1987, Grosjean et al. 1996) on natural substrates.

Statistical analysis. To compare settlement between the 2 habitats and depths, we carried out a factorial ANOVA with 3 fixed orthogonal factors (Time, Depth and Habitat) and their interactions. To test for significant differences in settlement among depths within the seagrass meadow, we used a 2-way ANOVA (fixed factors Time and Depth). Finally, to test for differences in settlement in the seagrass meadow between the foliar stratum and the rhizome, a factorial ANOVA with 3 fixed orthogonal factors (Time, Depth and Stratum) was used.

When overall significant differences were detected, a posteriori pairwise comparisons of means was performed using the Student-Newman-Keuls test (SNK; Zar 1989).

Prior to statistical analyses, normality and homogeneity of variance were checked for all data (Kolmogorov-Smirnov test and Cochran's $C$-test, respectively). We were unable to attain homoscedasticity even after trying several transformations of the variables studied, but as samples were large we considered ANOVA to be robust to departures from this assumption (Underwood 1997).

\section{RESULTS}

\section{Settlement variability}

Urchins settled in collectors consisted of postlarvae and newly metamorphosed juveniles (Gosselin \& Jangoux 1998), and no larvae were found. The mean size of the newly settled urchins was very similar in both habitats, with a TD of $0.34 \pm 0.04 \mathrm{~mm}$ (mean $\pm \mathrm{SD}$ ) for newly arrived settlers on the rock wall, and of $0.32 \pm$ $0.04 \mathrm{~mm}$ for those settled in the seagrass meadow.

Two main settlement peaks were observed for Paracentrotus lividus each year: one in spring-early summer, and a second in autumn-winter (Fig. 1). The spring peak was generally higher than the autumn one, especially in 2000. Indeed, a very strong interannual variability in settlement was observed (Fig. 1), mostly concerning the importance of the spring peaks. Settlers of the echinoid Arbacia lixula were only found during the autumn-winter peaks (results not shown).

Settlement was generally higher on the rock wall than on the seagrass meadow (Fig. 1); these differences increased during the 2000 spring peak (see significant interaction in Table 1), when settlement on the rock wall was significantly higher (up to 3 times) than in the seagrass meadow (SNK test). 
No significant differences were found in settlement between 3 and $5 \mathrm{~m}$ depth at both habitats (Fig 2, Tables 1 \& 2). Within the seagrass meadow, settlement at $10 \mathrm{~m}$ depth was significantly lower than at 3 and $5 \mathrm{~m}$ (Fig. 2b, Table 2). In this case, the significant interaction term (Time $\times$ Depth) indicates a different time course at different depths (Table 2); such differences were due to the much higher settlement at 3 and $5 \mathrm{~m}$ than at $10 \mathrm{~m}$ during the spring peak of 2000 (SNK).

Settlement of Paracentrotus lividus on the seagrass meadow was generally higher on the leaf stratum than on the rhizome (Fig. 3), but differences were significant only in the first 2 wk of May 2000 (Table 3, SNK).

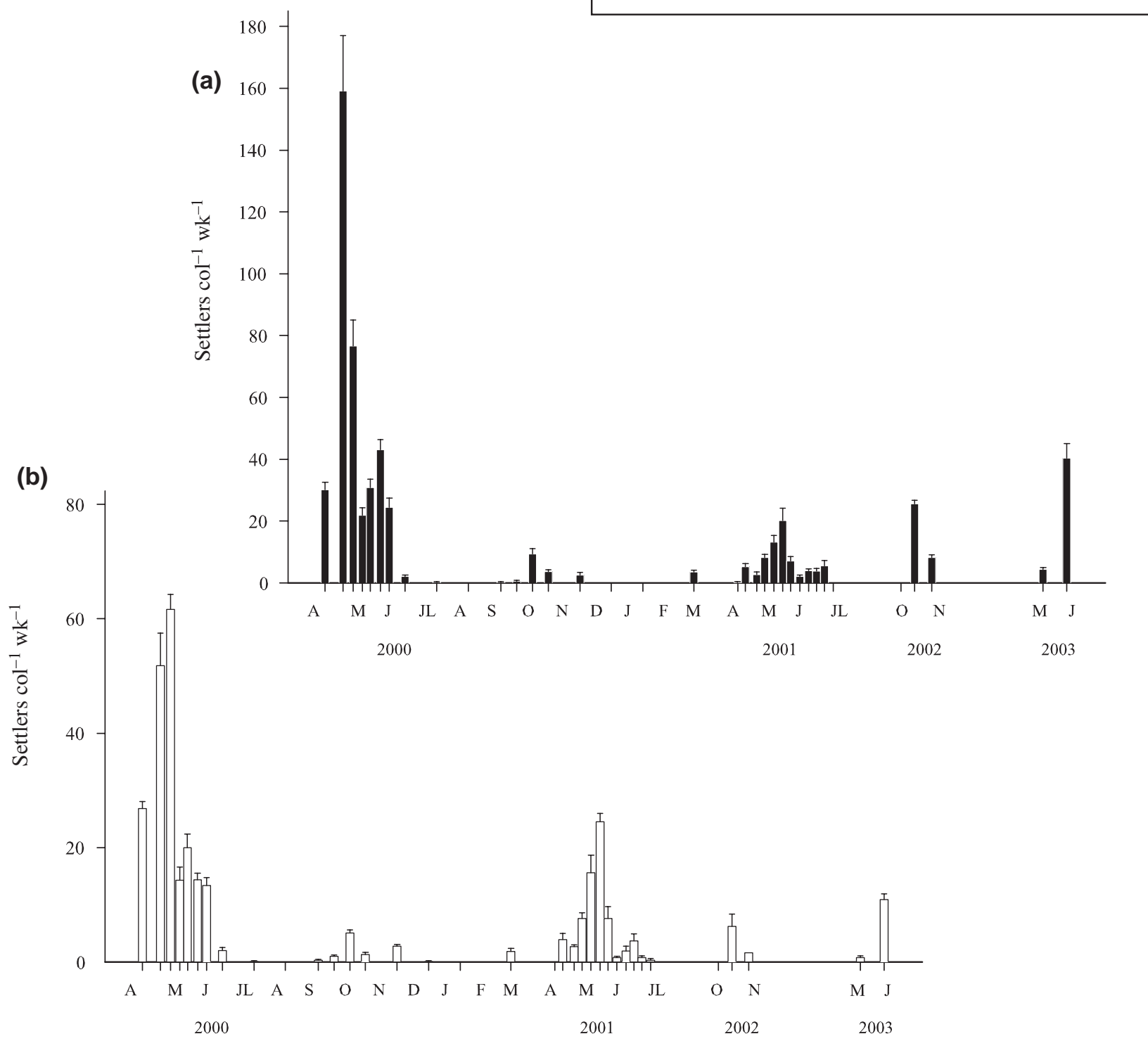

Fig. 1. Paracentrotus lividus. Time course of number of weekly settled urchins (settlers collector ${ }^{-1} \mathrm{wk}^{-1}$; mean $+\mathrm{SE}$ ) (a) on the rock wall and (b) in the seagrass meadow, sampled between April 2000 and June 2003 (3 and $5 \mathrm{~m}$ depth pooled). The $x$-axis is not to
Table 1. Paracentrotus lividus. Summary of the factorial 3-way ANOVA to assess significant differences in abundance of newly settled $P$. lividus measured from April 2000 to June 2003 between the 2 habitats (seagrass meadow and rock wall, $\mathrm{H})$, sampling time $(\mathrm{T})$, depth (3 and $5 \mathrm{~m}, \mathrm{D})$ and their interactions. $\mathrm{MS}=$ mean square, $\mathrm{df}=$ degrees of freedom, $\mathrm{ns}=$ not significant

\begin{tabular}{|lrrrc|}
\hline Effect & df & MS & $F$ & $p$ \\
\hline Time & 27 & 7618.3 & 43.281 & $<0.0001$ \\
Habitat & 1 & 4259.2 & 24.197 & $<0.0001$ \\
Depth & 1 & 68.3 & 0.388 & $\mathrm{~ns}$ \\
$\mathrm{~T} \times \mathrm{H}$ & 27 & 1638.9 & 9.311 & $<0.0001$ \\
$\mathrm{~T} \times \mathrm{D}$ & 27 & 42.4 & 0.241 & $\mathrm{~ns}$ \\
$\mathrm{H} \times \mathrm{D}$ & 1 & 200.0 & 1.136 & $\mathrm{~ns}$ \\
$\mathrm{~T} \times \mathrm{H} \times \mathrm{D}$ & 27 & 32.2 & 0.183 & $\mathrm{~ns}$ \\
Error & 310 & 176.0 & & \\
& & & & \\
\hline
\end{tabular}
wall and (b) in the seagrass meadow, sampled between April 2000 and June 2003 (3 and $5 \mathrm{~m}$ de
scale for 2002 and 2003. Note different scales on the $y$-axis

(b) 


\section{Recruitment and adult abundances}

On the rock wall, the population size-frequency distribution was bimodal, with a high proportion of recruits (i.e. individuals $<16 \mathrm{~mm}$ TD) and a second mode of large (6 cm TD) individuals (Fig. 4). In contrast, sizefrequency distributions on the shallow ( 3 to $5 \mathrm{~m}$ ) seagrass meadow were unimodal, dominated by large individuals (6 cm TD), with only a very small proportion, if any, of the population consisting of recruits (Fig. 4).

Fig. 5 depicts the size-frequency distributions obtained in September of each year. At this time the set-
Table 2. Paracentrotus lividus. Summary of the factorial 2 -way ANOVA to assess significant differences in abundance of newly settled P. lividus measured from April 2000 to June 2003 within the seagrass meadow between depths $(3,5$ and $10 \mathrm{~m}, \mathrm{D})$, sampling time $(\mathrm{T})$ and their interaction $(\mathrm{T} \times \mathrm{D}) . \mathrm{MS}=$ mean square, $\mathrm{df}=$ degrees of freedom

\begin{tabular}{|lrrrc|}
\hline Effect & df & \multicolumn{1}{c|}{ MS } & $F$ & p \\
\hline Time & 29 & 2189.42 & 82.336 & $<0.0001$ \\
Depth & 2 & 494.55 & 18.598 & $<0.0001$ \\
T $\times$ D & 58 & 60.60 & 2.279 & $<0.0001$ \\
Error & 230 & 26.59 & & \\
\hline
\end{tabular}

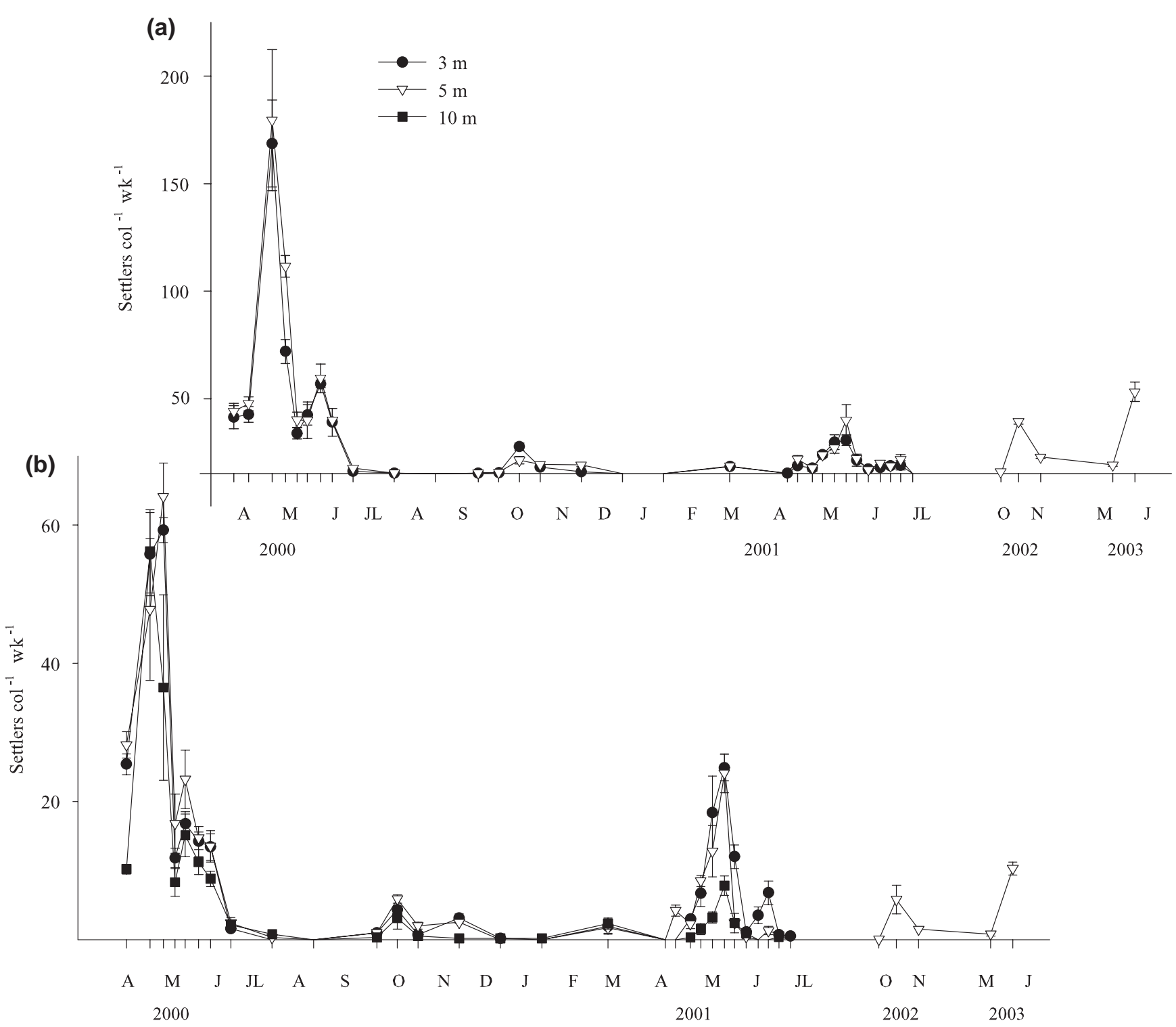

Fig. 2. Paracentrotus lividus. Abundance (settlers collector ${ }^{-1} \mathrm{wk}^{-1}$; mean $\pm \mathrm{SE}$ ) of newly settled urchins between April 2000 and June 2003 at (a) 2 depths on the rock wall and (b) 3 depths in the seagrass meadow. The $x$-axis is not to scale for 2002 and 2003. 


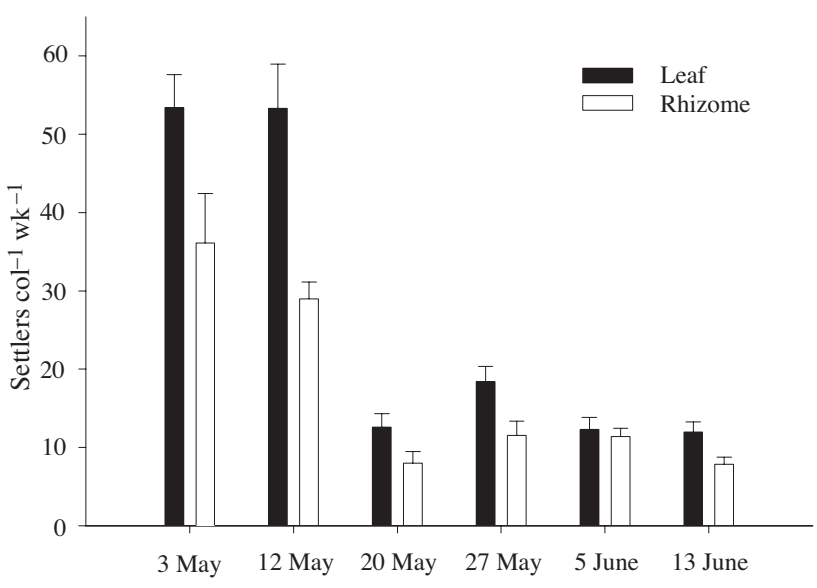

Fig. 3. Paracentrotus lividus. Number of newly settled urchins (settlers collector ${ }^{-1} \mathrm{wk}^{-1}$; mean $+\mathrm{SE}$ ) on 2 different strata (leaf canopy versus rhizome) within the seagrass meadow measured in spring-early summer 2000

tlers of the previous spring event should be clearly discernible as new recruits. During the $4 \mathrm{yr}$ sampled $(2000,2001,2002$ and 2003) recruitment occurred every year on the rock wall, and was especially high in 2001. In fact, the percentage of recruits doubled in 2001 and, on average, recruits represented $35 \pm 11 \%$ (mean $\pm \mathrm{SD}$ ) of the population (Figs. 4 \& 5). In contrast, hardly any recruitment was observed any year in the seagrass meadow (Figs. 4 \& 5). To ensure that we were not missing recruits in the seagrass meadow, 3 cores (16 $\mathrm{cm}$ diameter $\times 30 \mathrm{~cm}$ height) were extracted on 18 October 2000 from the rhizome-sediment layer (the so-called 'matte'; see Mateo et al. 1997) between 2.5 and $4 \mathrm{~m}$ depth, and exhaustively searched in the laboratory. No juveniles were encountered.

Table 3. Paracentrotus lividus. Summary of the factorial 3-way ANOVA to assess significant differences in abundance of newly settled $P$. lividus measured during the spring peak of 2000 (May to June) within the seagrass meadow between depths $(3,5$ and $10 \mathrm{~m}, \mathrm{D})$, stratum (leaf versus rhizome, S) sampling time $(\mathrm{T})$ and their interactions. $\mathrm{MS}=$ mean square, $\mathrm{df}=$ degrees of freedom, ns = not significant

\begin{tabular}{|lrrrc|}
\hline Effect & df & \multicolumn{1}{c}{ MS } & $F$ & $\mathrm{p}$ \\
\hline Time & 5 & 6475.02 & 62.361 & $<0.0001$ \\
Depth & 2 & 448.78 & 4.322 & 0.016 \\
Stratum & 1 & 3173.08 & 30.560 & $<0.0001$ \\
$\mathrm{~T} \times \mathrm{D}$ & 10 & 185.96 & 1.791 & $\mathrm{~ns}$ \\
$\mathrm{~T} \times \mathrm{S}$ & 5 & 533.59 & 5.139 & 0.0003 \\
$\mathrm{D} \times \mathrm{S}$ & 2 & 16.28 & 0.157 & $\mathrm{~ns}$ \\
$\mathrm{~T} \times \mathrm{S} \times \mathrm{D}$ & 10 & 134.42 & 1.295 & $\mathrm{~ns}$ \\
Error & 107 & 103.831 & & \\
& & & & \\
\hline
\end{tabular}

While the size structure did not differ appreciably between 3 and $5 \mathrm{~m}$ depth on the wall, all recruits recorded in the seagrass meadow were always encountered in the shallow meadow (approx. 2.5 to $3.5 \mathrm{~m}$ ). Within the meadow, no juveniles appeared at $5 \mathrm{~m}$ and neither juveniles nor adults were found at $10 \mathrm{~m}$ depth.

In the shallow seagrass meadow (i.e. 3 and $5 \mathrm{~m}$ depth) the density of Paracentrotus lividus was $4.7 \pm$ 0.2 ind. $\mathrm{m}^{-2}$ (mean $\pm \mathrm{SE}$ ) and very constant throughout the $4 \mathrm{yr}$ of sampling (Fig. 6). In contrast, mean density on the rock wall was 3 times higher $(15.0 \pm 1.0$ ind. $\mathrm{m}^{-2}$ ), ranging approximately from 5 to 28 ind. $\mathrm{m}^{-2}$, with noticeable variation over the sampling period, although no consistent seasonal trend could be substantiated (Fig. 6).

\section{DISCUSSION}

The aspects of the population dynamics studied for Paracentrotus lividus were clearly different between the habitats investigated; not only was adult density higher on the rock wall (and more variable with time), but adult size distribution also differed between habitats, as did settlement. Moreover, no appreciable successful recruitment took place in the seagrass meadow during the period studied. Therefore, markedly different processes appear to lie behind the apparently stable population structures observed (Romero et al. 1999). Whereas settlement and recruitment appear to influence adult populations on the rock wall, our results suggest that the population in the seagrass meadow may not be sustained by local recruitment. We cannot rule out that low but steady recruitment or occasional good years of recruitment (Ebert 1983) combined with low mortality rates could be sufficient to maintain the population in the seagrass meadow. However, the almost complete absence of urchins of intermediate sizes during the years of study indicate that migration from neighbouring rocky substrates (walls and boulders) is a more likely explanation, as suggested for other populations of this sea urchin species (e.g. Turon et al. 1995).

Strong temporal variability is a general feature in sea urchin settlement and recruitment (e.g. Ebert et al. 1994, Balch \& Scheibling 2000, Lamare \& Barker 2001). A single settlement peak during early summer has often been recorded for Paracentrotus lividus (Azzolina \& Willsie 1987, Lozano et al. 1995, Sala \& Zabala 1996, Hereu et al. 2004). However, settlement was only actually measured in the latter study, whereas in other works it was inferred from the observation of recruits. On the contrary, other authors have suggested the existence of a longer settlement period 
Rock wall

Rock wall
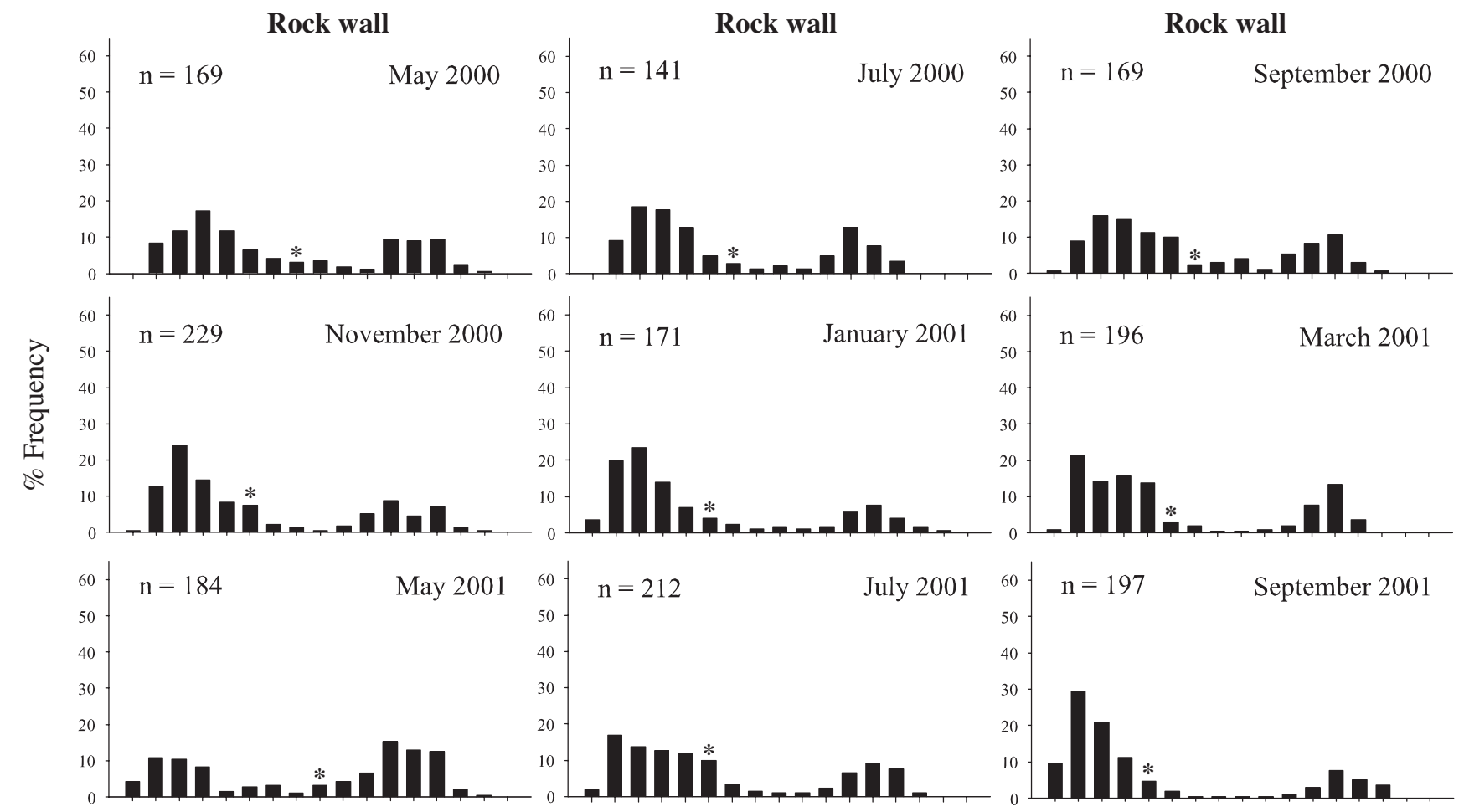

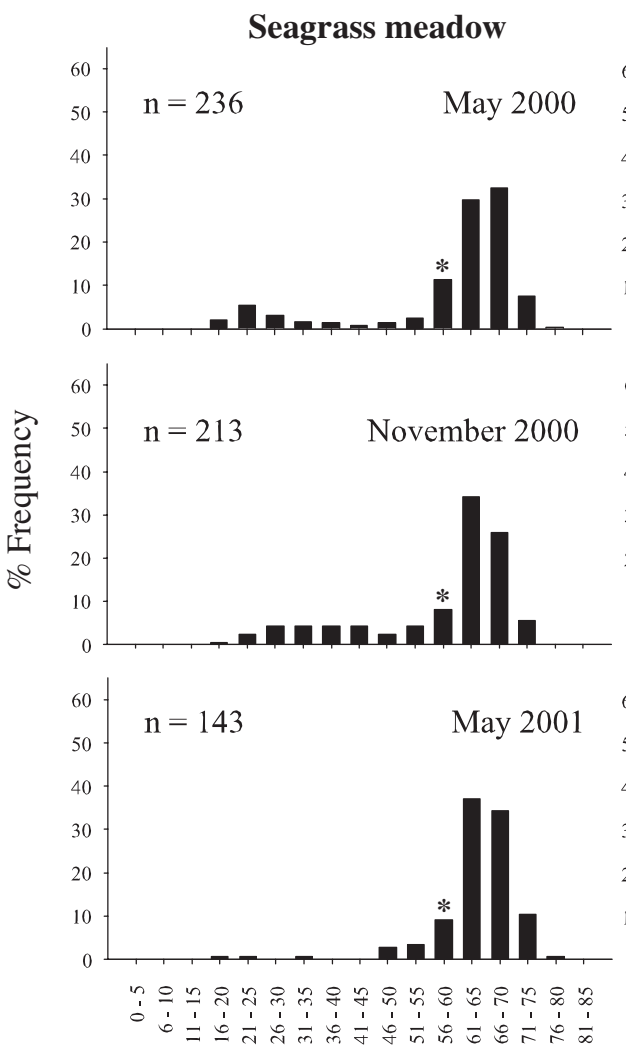

Size Class (mm)
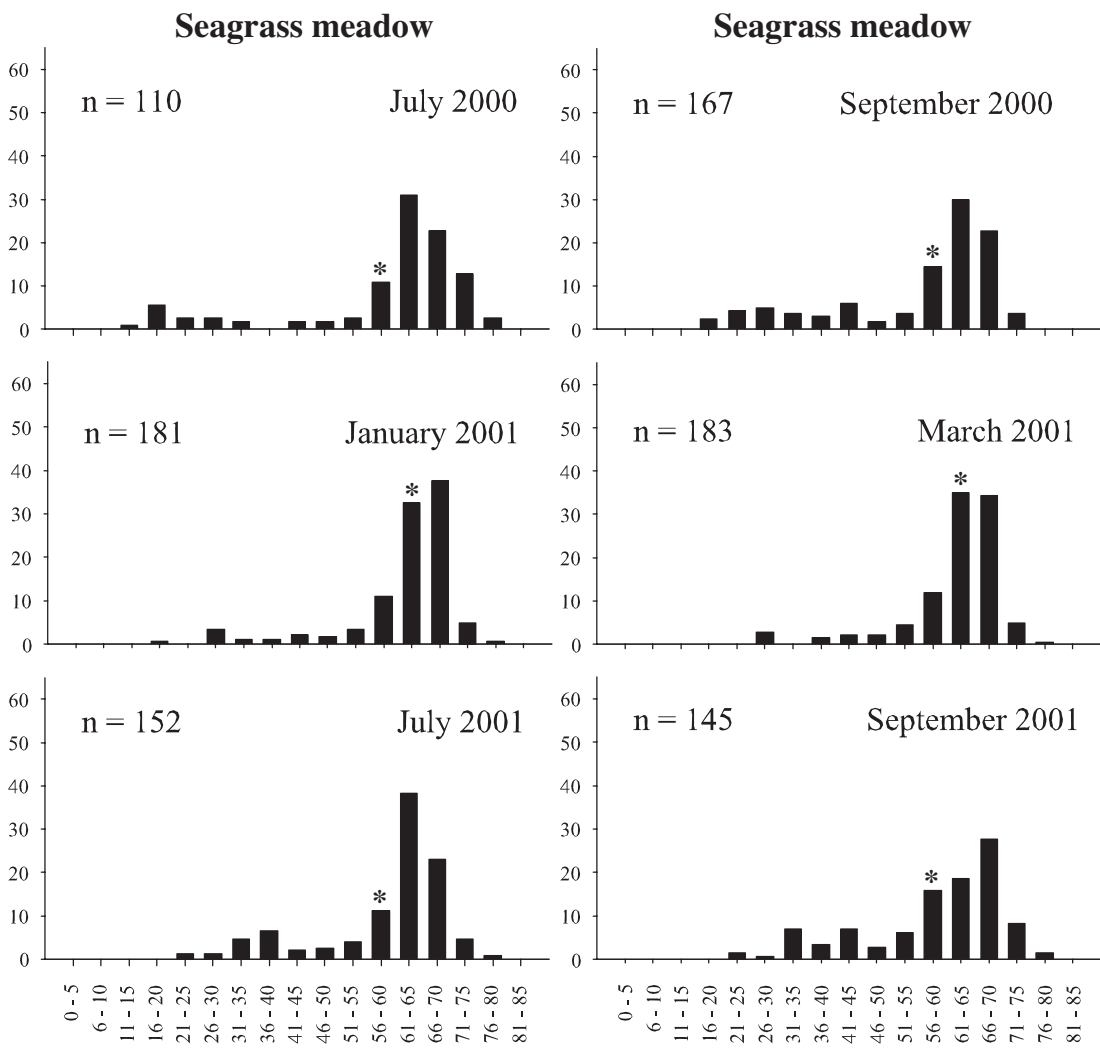

Size Class (mm)
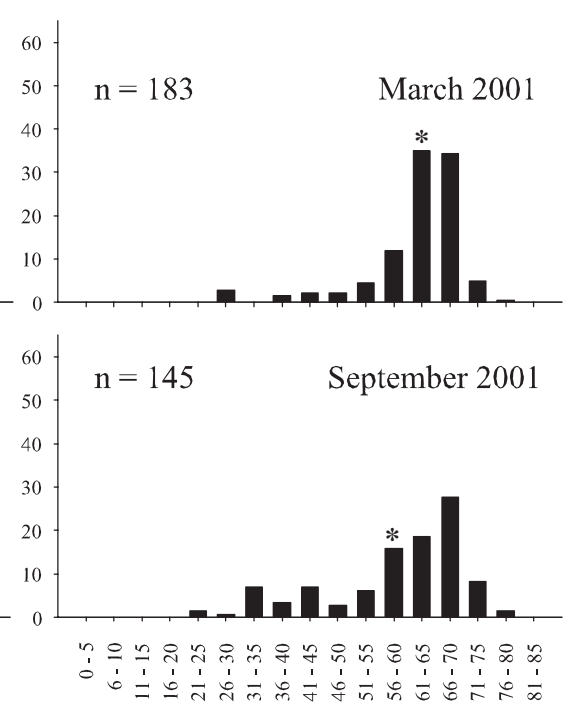

Size Class (mm)

Fig. 4. Paracentrotus lividus. Size-frequency distributions of juvenile and adult individuals (\%) on the rock wall and in the seagrass meadow sampled between May 2000 and September 2001 ( 3 and $5 \mathrm{~m}$ depth pooled). The mean test diameter of each sampling time is indicated $(*) . \mathrm{n}=$ number of urchins in each sample 

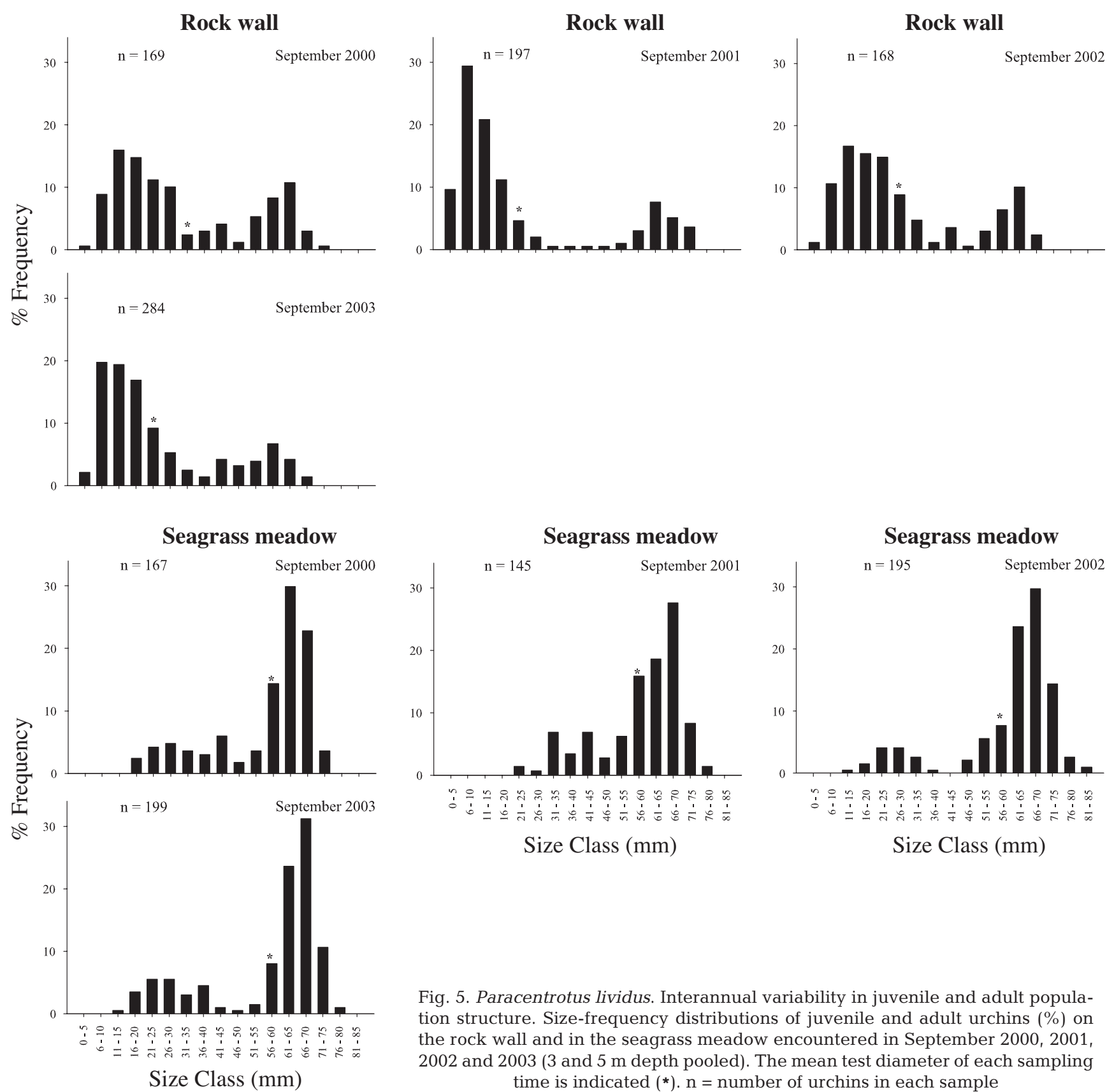

Fig. 5. Paracentrotus lividus. Interannual variability in juvenile and adult population structure. Size-frequency distributions of juvenile and adult urchins (\%) on the rock wall and in the seagrass meadow encountered in September 2000, 2001, 2002 and 2003 ( 3 and $5 \mathrm{~m}$ depth pooled). The mean test diameter of each sampling time is indicated $(*) . \mathrm{n}=$ number of urchins in each sample

or 2 distinct peaks of $P$. lividus settlement in spring and autumn (Verlaque 1984, Fenaux et al. 1987, Lopez et al. 1998, Guettaf et al. 2000). Again, none of these studies measured settlement directly but inferred it either from larval data, from recruitment or from the gonadic cycle of adults. Our study clearly reveals the presence of an autumn-winter settlement peak which is smaller than the spring peak of the same year, but of the same order of magnitude as spring peaks of other years. Thus it is reasonable to accept the often suggested existence of 2 spawning periods for $P$. lividus (reviewed in Boudouresque \& Verlaque 2001), although histological data of gonads is needed to confirm this.

The differences in settlement observed between the 2 habitats could be explained by the higher abundance of potential settlement induction cues on the rock wall. Larval metamorphosis, settlement or recruitment of Paracentrotus lividus and other sea urchin species are often induced by the presence of red coralline algae (e.g. Harrold et al. 1991, Grosjean et al. 1996) and/or by the presence of conspecifics (Highsmith 1982, Cellario \& Fenaux 1990, Gosselin \& Jangoux 1998, but see Gosselin \& Jangoux 1996). The abundances of both 

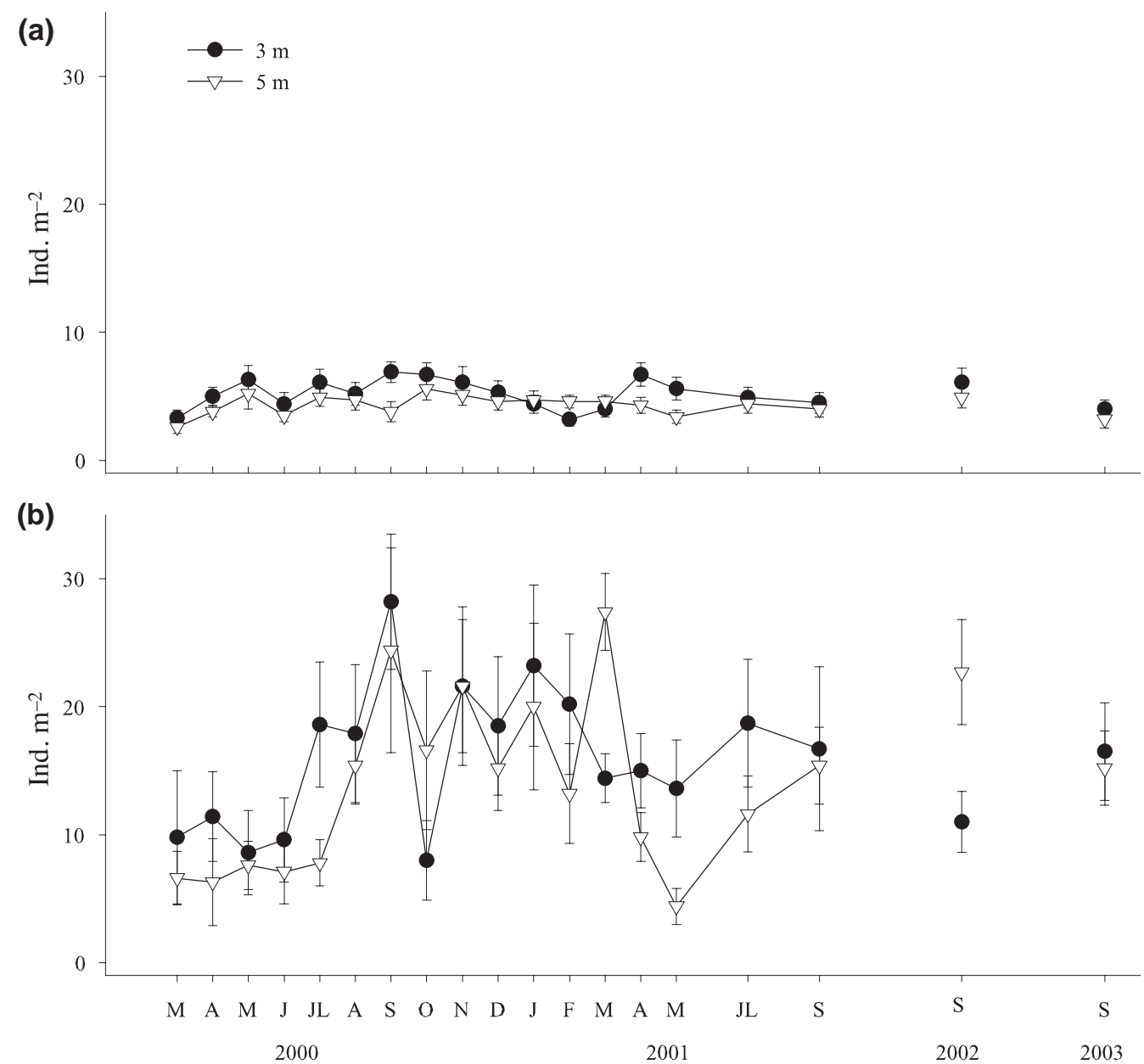

Fig. 6. Paracentrotus lividus. Time course of adult population density (ind. $\mathrm{m}^{-2}$; mean $\pm \mathrm{SE}$ ) on (a) the rock wall and (b) the sea grass meadow sampled between May 2000 and September 2003. The $x$-axis is not to scale for 2002 and 2003

coralline algae (F. Tomas unpubl. data) and conspecifics were noticeably higher on the rock wall. However, differences in settlement between the 2 habitats could also be the result of the action of factors affecting distribution of larvae in the water column, such as water circulation patterns (Ebert \& Russell 1988, Pedrotti \& Fenaux 1996) or biotic factors like larval aggregation for food or larval mortality through predation or food limitation (Ebert 1983, Metaxas \& Young 1998). Furthermore, settlement of $P$. lividus in the study area is very patchy and follows a highly heterogeneous distribution even at a scale of tens of metres (Hereu et al. 2004). We cannot discern whether larvae actively selected a given habitat or whether the distribution of settlers observed was due to the spatial patchiness of larvae in the water column. Nevertheless, the net result was a pattern of higher settlement on the rock wall than in the seagrass bed, which was consistent over time. Therefore, a higher amount of potential recruits actually arrived on the rock wall during the period studied, and could explain, at least in part, the differences observed in adult abundances (Gaines \& Roughgarden 1985).

Post-settlement processes are crucial in determining the success of recruitment. Early benthic phases of the life-history are often subjected to strong mortality in benthic invertebrates (e.g. Keesing et al. 1993, Gosselin \& Qian 1997, Hunt \& Scheibling 1997) and in sea urchins in particular (e.g. Azzolina \& Willsie 1987, López et al. 1998). Dislodgement, physical conditions and disease are some of the factors which influence the success of juveniles after settlement (McEdward \& Miner 2001). Predation is also an important process in determining juvenile mortality of many invertebrates including sea urchins (Tegner \& Dayton 1981, Keough \& Downes 1982, Ebert 1983). Indeed, the generally cryptic behaviour of juveniles of Paracentrotus lividus and other echinoid species, which hide in crevices or 
under boulders, has often been attributed to a predator avoidance strategy (Carpenter 1984, Verlaque 1984, Sala \& Zabala 1996).

Whereas recruitment on the rock wall appears to be coupled to settlement (e.g. after a strong settlement event in 2000, the percentage of recruits doubled the following year), post-settlement mortality appears to be limiting the population of Paracentrotus lividus in the seagrass meadow studied, as no appreciable recruitment was observed during the $4 \mathrm{yr}$ studied despite the arrival of settlers. In fact, only 31 individuals with TD $<21 \mathrm{~mm}$ were found during the $11 \mathrm{sam}$ pling events performed (out of a total of 1924 individuals counted), all of them thoroughly hidden between the rhizomes in the shallowest part of the meadow $(2.5$ to $3.5 \mathrm{~m}$ ) and never smaller than $14 \mathrm{~mm}$ TD. The most obvious difference between the shallower part of the meadow and the deeper parts (5 and $10 \mathrm{~m}$ ), where no recruits were observed during the whole period of study, is the grade of rhizome burial by sand at the latter. It is plausible that rhizomes covered with sand do not provide an adequate substrate for recruitment due to the instability of the sediment and burial and smothering of juveniles. Recruitment in this and other Posidonia oceanica meadows appears to take place mostly between the rhizomes with sparse or no seagrass shoots (Boudouresque et al. 1980, Azzolina \& Willsie 1987). However, no differential settlement was observed on the rhizomes in our study, so the distribution of recruits must result from post-settlement events.

Predation pressure on Paracentrotus lividus is probably very high in both habitats, as the main predators of juvenile and adult $P$. lividus, such as the fish Diplodus sargus, $D$. vulgaris, Labrus merula, $L$. viridis and Coris julis or the sea star Marthasterias glacialis (see Boudouresque \& Verlaque 2001 for a review), are remarkably abundant at the study site (García-Rubies \& Zabala 1990, F. Tomas pers. obs.). Nevertheless, the crevices in the rock wall where juveniles are often found (Verlaque 1984, Levitan \& Genovese 1989, Sala \& Zabala 1996) probably offer sufficient refuge from predators to enable some successful recruitment. In addition, the presence of adults, which are very abundant on the rock wall, can also favour recruitment, as juveniles hide between the spines of or underneath the adults (Tegner \& Dayton 1981, Rogers-Bennett et al. 1995, F. Tomas pers. obs.). In fact, the stability of the bimodal size distribution on the rock wall may also be the result of predation pressure (Sala \& Zabala 1996), since, as juveniles grow, they reach a threshold size (2 to $3 \mathrm{~cm}$ TD) at which refuges are no longer available and thus they become vulnerable to predators (Tegner \& Dayton 1981, Sala \& Zabala 1996).

The abundance of Paracentrotus lividus appears to decrease with depth, and sea urchins are mostly found between 0 and $10 \mathrm{~m}$ depth on hard substrates (Lozano et al. 1995, Chelazzi et al. 1997, Boudouresque \& Verlaque 2001). No distinct depth distribution pattern was observed in settlement, recruitment or adult population structure on the rock wall within the depth range studied (3 to $5 \mathrm{~m}$ depth). In contrast, a clear decrease in adult abundance was observed with depth in the seagrass meadow (no urchins present at $10 \mathrm{~m}$ ), which was in accordance with the settlement data obtained (lower settlement rates at $10 \mathrm{~m}$ ). Given the lack of recruitment observed below $4 \mathrm{~m}$ depth during the period studied, and the stability of the population in the meadow (no $P$. lividus have been observed at $10 \mathrm{~m}$ depth in this meadow for at least $10 \mathrm{yr}$; Romero et al. 1999), the absence of urchins at $10 \mathrm{~m}$ depth is probably the result of other processes rather than, or in combination with, low settlement.

In summary, we found noticeable differences in Paracentrotus lividus settlement at various levels: interannual, seasonal and between nearby habitats. The depth range studied at both habitats ( 3 to $5 \mathrm{~m}$ ) and the stratum within the seagrass meadow seemed to be less important. Despite the arrival of settlers at both habitats, the population in the seagrass meadow appears to be recruitment-limited (Karlson \& Levitan 1990) and probably mainly sustained by external entrances, whereas recruitment roughly correlated with variation in settlement on the rock wall. Nevertheless, to fully establish the importance of settlement in determining recruitment and adult population patterns on the rock wall a longer time frame is needed (see Sala et al. 1998, Hereu et al. 2004). Our study stresses the importance of prolonged sampling periods when there is high interannual variability. Most of the significant differences in settlement were found during the strong settlement peak of spring 2000. Had we missed this episode, our conclusions may have been different. Punctual events seem to be highly relevant to the dynamics of pluriannual species such as sea urchins, and samplings should be designed to try to capture these events.

The lack of successful recruitment in the seagrass meadow despite noticeable settlement poses intriguing questions as to the cost of these 'errors' in settlement and as to the evolutive forces that shape larval behaviour at settlement. Why did larvae not avoid a predictably dangerous habitat for juveniles? Sea urchin outbreaks in seagrass meadows (e.g. Verlaque \& Nédelec 1983, Ruiz et al. 2001, F. Tomas pers. obs.) point to sporadic successful years that may counteract mortality in other years. The factors which can reverse the observed failure of recruitment (e.g. eutrophication phenomena) are not well understood but may hold the key to the particular dynamics observed in this community. 
Acknowledgements. This work was supported by grants REN2002-04020-C02-02/MAR and GRC 2001 SGR 00093. The authors wish to thank P. López-Sendino, R. Leach, B. Comellas and M. de Cáceres for field and laboratory assistance. Special thanks go to B. Hereu for advice, comments and field and laboratory support, without whom this work would not have been possible.

\section{LITERATURE CITED}

Alcoverro T, Duarte C, Romero J (1997) The influence of hervibores on Posidonia oceanica epiphytes. Aquat Bot 56: 93-104

Azzolina JF (1988) Contribution a l'étude de la dynamique des populations de l'oursin comestible Paracentrotus lividus (Lmck). Croissance, Recrutement, Mortalite, Migrations. PhD thesis, Université d'Aix-Marseille II

Azzolina JF, Willsie A (1987) Abondance des juveniles de Paracentrotus lividus au sein de l'herbier a Posidonia oceanica. In: Boudouresque CF (ed) Colloque international sur Paracentrotus lividus et les oursins comestibles. GIS Posidonie, Marseille, p 159-167

Balch T, Scheibling RE (2000) Temporal and spatial variability in settlement and recruitment of echinoderms in kelp beds and barrens in Nova Scotia. Mar Ecol Prog Ser 205: 139-154

Balch T, Scheibling RE, Harris LG, Chester CM, Robinson SMC (1998) Variation in settlement of Strongylocentrotus droebachiensis in the northwest Atlantic: effects of spatial scale and sampling method. In: Mooi R, Telford M (eds) Echinoderms: San Francisco. AA Balkema, Rotterdam, p 555-560

Benedetti-Cecchi L, Cinelli F (1995) Habitat heterogeneity, sea urchin grazing and the distribution of algae in littoral rock pools on the west coast of Italy (western Mediterranean). Mar Ecol Prog Ser 126:203-212

Boudouresque CF, Verlaque M (2001) Ecology of Paracentrotus lividus. In: Lawrence JM (ed) Edible sea urchins: biology and ecology, Vol 32. Elsevier Science, Amsterdam, p $177-216$

Boudouresque CF, Nédelec $H$, Shepherd SA (1980) The decline of a population of the sea urchin Paracentrotus lividus in the bay of Port-Cros (Var, France). Trav Sci Parc Nat Port-Cros 6:242-251

Carpenter RC (1984) Predator and population density control of homing behavior in the Caribbean echinoid Diadema antillarum. Mar Biol 82:101-108

Cellario C, Fenaux L (1990) Paracentrotus lividus (Lamarck) in culture (larval and benthic phases): parameters of growth observed during two years following metamorphosis. Aquaculture 84:173-188

Chelazzi G, Serra G, Bucciarelli G (1997) Zonal recovery after experimental displacement in two sea urchins co-occurring in the Mediterranean. J Exp Mar Biol Ecol 212:1-7

Ebert TA (1983) Recruitment in echinoderms. In: Jangoux M, Lawrence JM (eds) Echinoderm studies. AA Balkema, Rotterdam, p 169-203

Ebert TA, Russell MP (1988) Latitudinal variation in size structure of the west coast purple sea urchin: a correlation with headlands. Limnol Oceanogr 33:286-294

Ebert TA, Schroeter SC, Dixon JD, Kalvass P (1994) Settlement patterns of red and purple sea urchins (Strongylocentrotus franciscanus and $S$. purpuratus) in California, USA. Mar Ecol Prog Ser 111:41-52

Fenaux L, Etienne M, Quelart G (1987) Suivi ecologique d'un peuplement de Paracentrotus lividus (Lamarck) dans la baie de Villefranche sur Mer. In: Boudouresque CF (ed) Colloque international sur Paracentrotus lividus et les oursins comestibles. GIS Posidonie, Marseille, p 187-197

Fogarty MJ, Sissenwine MP, Cohen EB (1991) Recruitment variability and the dynamics of exploited marine populations. Trends Ecol Evol 6:241-246

Gaines SD, Roughgarden J (1985) Larval settlement rate: a leading determinant of structure in an ecological community of the marine intertidal zone. Proc Natl Acad Sci USA 82:3707-3711

García-Rubies A, Zabala M (1990) Effects of total fishing prohibition on the rocky fish assemblages of Medes Islands marine reserve (NW Mediterranean). Sci Mar 54:317-328

Gosselin LA, Qian PY (1997) Juvenile mortality in benthic marine invertebrates. Mar Ecol Prog Ser 146:265-282

Gosselin P, Jangoux M (1996) Induction of metamorphosis in Paracentrotus lividus larvae (Echinodermata, Echinoidea). Oceanol Acta 19:293-296

Gosselin P, Jangoux M (1998) From competent larva to exotrophic juvenile: a morphofunctional study of the perimetamorphic period of Paracentrotus lividus (Echinodermata, Echinoidea). Zoomorphology 118:31-43

Grosjean P, Spirlet C, Jangoux M (1996) Experimental study of growth in the echinoid Paracentrotus lividus (Lamarck, 1816) (Echinodermata). J Exp Mar Biol Ecol 201:173-184

Guettaf M, San Martin GA, Francour P (2000) Interpopulation variability of the reproductive cycle of Paracentrotus lividus (Echinodermata: Echinoidea) in the south-western Mediterranean. J Mar Biol Assoc UK 80:899-907

Hagen NT (1995) Recurrent destructive grazing of successionally immature kelp forests by green sea urchins in Vestfjorden, Northern Norway. Mar Ecol Prog Ser 123:95-106

Harrold C, Lisin S, Light KH, Tudor S (1991) Isolating settlement from recruitment of sea urchins. J Exp Mar Biol Ecol 147:81-94

Hereu B, Zabala M, Linares C, Sala E (2004) Temporal and spatial variability in settlement of the sea urchin Paracentrotus lividus (Lamarck). Mar Biol 144:1011-1018

Highsmith RC (1982) Induced settlement and metamorphosis of sand dollar (Dendraster excentricus) larvae in predatorfree sites: adult sand dollar beds. Ecology 63:329-337

Hunt HL, Scheibling RE (1997) Role of early post-settlement mortality in recruitment of benthic marine invertebrates. Mar Ecol Prog Ser 155:269-301

Jangoux M, Lawrence JM (1983) Echinoderm studies. AA Balkema, Rotterdam

Karlson RH, Levitan DR (1990) Recruitment-limitation in open populations of Diadema antillarum: an evaluation. Oecologia 82:40-44

Keesing JK, Cartwright CM, Hall KC (1993) Measuring settlement intensity of echinoderms on coral reefs. Mar Biol 117: 399-407

Kempf M (1962) Recherches d'écologie comparée sur Paracentrotus lividus (Lmk) et Arbacia lixula (L.) I. Rec Trav St Mar End 25:47-116

Keough MJ, Downes BJ (1982) Recruitment of marine invertebrates: the role of active larval choices and early mortality. Oecologia 54:348-352

Lamare MD, Barker MF (2001) Settlement and recruitment of the New Zealand sea urchin Evechinus chloroticus. Mar Ecol Prog Ser 218:153-166

Lawrence JM (2001) Edible sea urchins: biology and ecology, Vol 32. Elsevier Science, Amsterdam

Lawrence JM, Sammarco PW (1982) Effects of feeding on the environment: Echinoidea. In: Jangoux M, Lawrence JM (eds) Echinoderm nutrition. AA Balkema, Rotterdam, p 499-519 
Levitan DR, Genovese J (1989) Substratum-dependent predator-prey dynamics: patch reefs as refuges from gastropod predation. J Exp Mar Biol Ecol 130:111-118

López S, Turon X, Montero E, Palacín C, Duarte CM, Tarjuelo I (1998) Larval abundance, recruitment and early mortality in Paracentrotus lividus (Echinoidea). Interannual variability and plankton-benthos coupling. Mar Ecol Prog Ser 172:239-251

Lozano J, Galera J, López S, Turon X, Palacín C, Morera G (1995) Biological cycles and recruitment of Paracentrotus lividus (Echinodermata: Echinoidea) in two contrasting habitats. Mar Ecol Prog Ser 122:179-191

Mateo MA, Romero J, Pérez M, Littler M, Littler D (1997) Dynamics of millenary organic deposits resulting from the growth of the Mediterranean seagrass Posidonia oceanica. Estuar Coast Shelf Sci 44:103-110

McClanahan TR (1998) Predation and the distribution and abundance of tropical sea urchin populations. J Exp Mar Biol Ecol 221:231-255

McEdward LR, Miner BG (2001) Echinoid larval ecology. In: Lawrence JM (ed) Edible sea urchins: biology and ecology, Vol 32. Elsevier Science, Amsterdam, p 59-78

Metaxas A, Young CM (1998) Responses of echinoid larvae to food patches of different algal densities. Mar Biol 130: 433-445

Minchinton TE, Scheibling RE (1991) The influence of larval supply and settlement on the population structure of barnacles. Ecology 72:1867-1879

Paine RT (1992) Food-web analysis through field measurements of per capita. interaction strength. Nature 355:73-75

Palacín C, Giribert G, Carner S, Dantart L, Turon X (1998a) Low densities of sea urchins influence the structure of algal assemblages in the western Mediterranean. J Sea Res 39:281-290

Palacín C, Turon X, Ballesteros M, Giribert G, López S (1998b) Stock evaluation of three littoral echinoid species on the Catalan Coast (north-western Mediterranean). PSZN I: Mar Ecol 19(3):163-177

Pedrotti ML, Fenaux L (1996) Distribution of echinoderm larval populations in the geostrophic frontal jet of the eastern Alboran Sea. Oceanol Acta 19:385-395

Rogers-Bennett L, Bennett WA, Fastenau HC, Dewees CM (1995) Spatial variation in red sea urchin reproduction and morphology: implications for harvest refugia. Ecol Appl 5: 1171-1180

Romero J, Pérez M, Renom P, Invers O, Mateo MA, Tomas F, Manzanera M, de Pedro X (1999) Seguimiento de la pradera de Posidonia oceanica de las Islas Medes. Ejercicio de 1999. In: Zabala M (ed) Seguiment temporal de les Illes Medes. Exercici 1999, Departament de Medi Ambient, Generalitat de Catalunya, p 9-18

Ruiz JM, Pérez M, Romero J (2001) Effects of fish farm loading on seagrass (Posidonia oceanica). Distribution, growth

Editorial responsibility: Otto Kinne (Editor), Oldendorf/Luhe, Germany and photosynthesis. Mar Pollut Bull 42:749-760

Sala E, Graham MH (2002) Community-wide distribution of predator-prey interaction strength in kelp forests. Proc Natl Acad Sci USA 99:3678-3683

Sala E, Zabala M (1996) Fish predation and the structure of the sea urchin Paracentrotus lividus populations in the NW Mediterranean. Mar Ecol Prog Ser 140:71-81

Sala E, Ribes M, Hereu B, Zabala M, Alvà V, Coma R, Garrabou J (1998) Temporal variability in abundance of the sea urchins Paracentrotus lividus and Arbacia lixula in the northwestern Mediterranean: comparison between a marine reserve and an unprotected area. Mar Ecol Prog Ser 168:135-145

San Martin G (1995) Contribution a la gestion des stocks d'oursins: étude des populations et transplantantations de Paracentrotus lividus à Marseille (France, Méditerranée) et production de Loxechinus albus à Chiloe (Chili, Pacifique). PhD thesis, Faculté des Sciences de Luminy, Université d'Aix-Marseille II

Scheibling RE, Hennigar AW, Balch T (1999) Destructive grazing, epiphytism, and disease: the dynamics of sea urchin-kelp interactions in Nova Scotia. Can J Fish Aquat Sci 56:2300-2314

Tegner M, Dayton PK (1981) Population structure, recruitment and mortality of two sea urchins (Strongylocentrotus franciscanus and $S$. purpuratus) in a kelp forest. Mar Ecol Prog Ser 5:255-268

Turon X, Giribert G, López S, Palacín C (1995) Growth and population structure of Paracentrotus lividus (Echinodermata: Echinoidea) in two contrasting habitats. Mar Ecol Prog Ser 122:193-204

Underwood AJ (1997) Experiments in ecology. Cambridge University Press, Cambridge

Underwood AJ, Fairweather PJ (1989) Supply-side ecology and benthic marine assemblages. Trends Ecol Evol 4: $16-20$

Valentine JF, Heck Jr KL (1999) Seagrass herbivory: evidence for the continued grazing of marine grasses. Mar Ecol Prog Ser 176:291-302

Verlaque M (1984) Biologie des juvéniles de l'oursin herbivore Paracentrotus lividus (lamarck): séléctivité dur broutage et impact de l'espèce sur les communautés algales de substrat rocheux en Corse (Méditerranée, France). Bot Mar 27:401-424

Verlaque M, Nédelec H (1983) Note préliminaire sur les relations biotiques Paracentrotus lividus (LMK.) et herbier de Posidonies. Rapp Comm Int Mer Médit 28:157-158

Watanabe J, Harrold C (1991) Destructive grazing by sea urchins Strongylocentrotus spp. in a central California kelp forest: potential roles of recruitment, depth, and predation. Mar Ecol Prog Ser 71:125-141

Zar JH (1989) Biostatistical analysis. Prentice-Hall, Englewood Cliffs, NJ

Submitted: November 24, 2003; Accepted: July 4, 2004

Proofs received from author(s): October 22, 2004 